\title{
A Modern Approach For Finding Minimization Cost In Transportation Problem
}

\section{G. Padma karthiyayini ${ }^{1}$, Dr.S. Ananthalakshmi ${ }^{2}$, Dr.R.Usha Parameswari ${ }^{3}$}

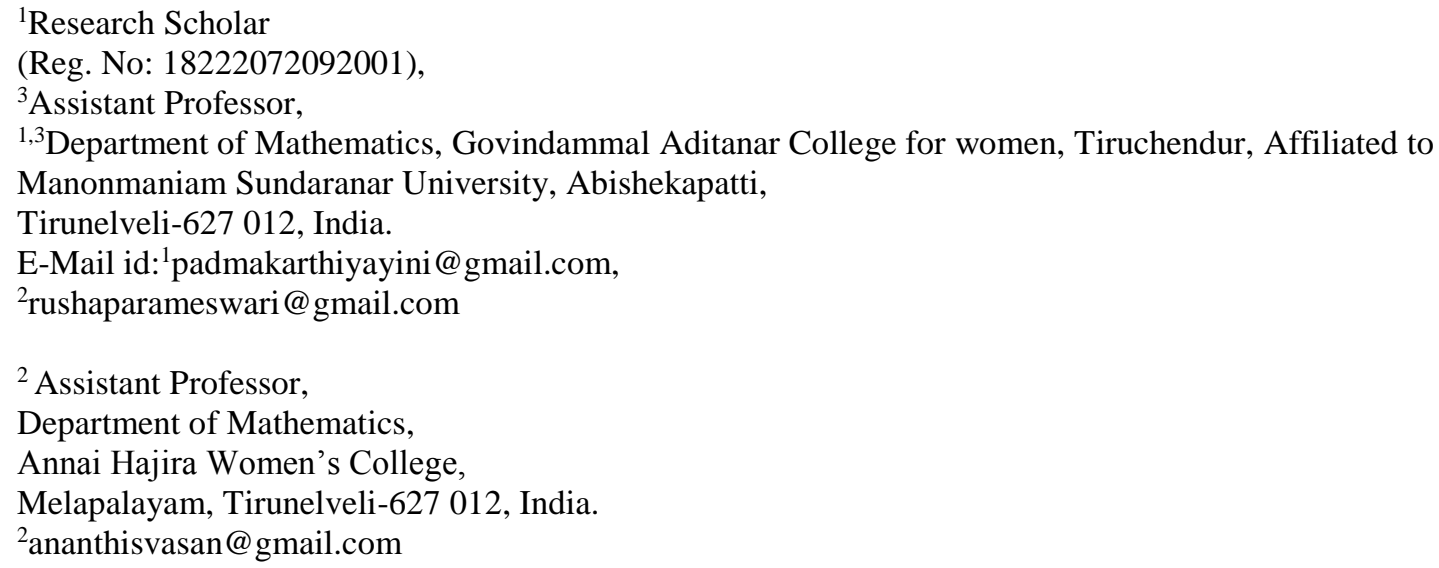

Article History:Received:11 January 2021; Accepted: 27 February 2021; Published online: 5 April 2021

Abstract: In this paper, the proposed technique is new and simple for obtaining an initial basic feasible solution (IBFS) of a transportation problem (TP). The objective of this paper is to find how to minimize the transportation cost (TC) by using a new approach. The method is illustrated with some numerical examples using algorithm.

Keywords: TP, IBFS, TC, Optimum Solution

\section{Introduction}

Transportation problem deals with the determination of a minimum-cost schedule for transporting a single commodity from a number of sources (warehouses) to a number of destinations (markets). This class of problem is basically a linear programming problem. In the transportation problem, the availability can be equal to the demand (balanced problem), the availability may be superior to the demand and the availability may be less than the demand. One of the first and important applications of the linear programming techniques, was the formulation and the solution of the transportation problem. The basic transportation problem was originally stated by Hitchcock [1].

The linear programming formulation and the associated systematic method for solution were first given in Dantzig [2]. To find optimal solutions to TP different methods are discussed in many papers $[3,4,7]$ and so far.

There are three well-known methods namely, North West Corner Method[5], Least Cost Method[5], Vogel's Approximation Method[5] to find the initial basic feasible solution of a transportation problem. In the last years, several researchers have developed alternative methods for finding initial basic feasible solution. This problem has been studied since long and is well known by S.M.Abul Kalam Azad, Md. Bellel Hossain, Md. Mizanur Rahman. [6], Md.Mizanur Rahman, Dr.Md.Bellel Hossain and Dr.Md. Mosharraf Hossain,[8], Mollah Mesbahuddin Ahmed, Aminur Rahman Khan, Md.Sharif Uddin, Faruque Ahmed [9], Aminur Rahman Khan, Adorian Vilcu, Nahid Sultana and Syed Sabbir Ahmed [10]. Z.A.M.S. Juman and N.G.S.A. Nawarathne [11]

In this paper, it has been focused in order to obtain a better initial basic feasible solution for the transportation problems with the numerical examples by using algorithm.

\section{Mathematical Formulation for Transportation Problem:}

In this section we further discuss about the mathematical formulation of the transportation problem (TP). The following notations are used in formulating the TP.

Notations

Supply quantity $\left(\mathrm{S}_{\mathrm{i}}\right)$ in units from $i^{\text {th }}$ supply node

The demand $\left(\mathrm{d}_{\mathrm{j}}\right)$ in units per unit time

$C_{i j}$ Unit transportation cost from $i^{\text {th }}$ supply node to $j^{\text {th }}$ demand node

$X_{i j}$ Number of units transported from $i^{t h}$ supply node to $j^{\text {th }}$ demand node

$m$ Total number of supply nodes (suppliers) 
$n$ Total number of demand nodes (buyers)

The basic problem (sometimes called as the general, classical or Hitchcock transportation problem) can be stated mathematically as follows.

$\operatorname{Min} \sum_{i=1}^{m} \sum_{j=1}^{n} C_{i j} X_{i j}$

Subject to

$$
\begin{aligned}
& \sum_{j=1}^{n} X_{i j} \leq S_{i}, \quad \mathrm{i}=1 \text { to } \mathrm{m} \\
& \sum_{i=1}^{m} X_{i j} \geq d_{j}, \quad \mathrm{j}=1 \quad \text { to } \mathrm{n}
\end{aligned}
$$

Where $X_{\mathrm{ij}} \geq 0$ for all $\mathrm{i}, \mathrm{j}$

A necessary and sufficient condition for the existence of a feasible solution to the transportation problem is; $\sum_{i=1}^{m} S_{i}=\sum_{j=1}^{n} d_{j}$

This means that the total supply is equal to total demand. Then the Transportation problem is called as a Balanced Transportation Problem. If not the problem is called as an Unbalanced Transportation Problem. Although, TP can be solved by the simplex algorithm.

\section{PROPOSED ALGORITHM:}

Step 1:

Step 2:

Construct the transportation matrix from the given transportation problem.

whether the TP is balanced or not, if not, make it balanced.

Step 3:

Subtract the smallest entry of every row from each of the element of the subsequent row of the transportation table and place them on the left - top of the corresponding elements.

Step 4: elements.

Apply the same operation on each of the column and put the value on the left-bottom of the corresponding

Step 5: and step 4.

In the next transportation table, the entries are the summation of left-top and left-bottom elements of step 3

Step 6:

From the transportation table choose the minimum cost, and subtract minimum cost from each of the cost valued cells of the transportation table. If the minimum cost appears in more than one cell, choose any one of them arbitrarily.

Step 7:

Start the allocation from minimum of supply/demand. Allocate this minimum of supply/demand in the place of minimum cost cell. If the demand is satisfied, delete the column. If it is supply, delete the row.

Step 8:

Now identify the minimum allocation cell value and allocate minimum of supply/demand at the place of selected allocation table. Suppose in the case of same allocation cell values, Select the allocation cell value where minimum allocation can be made. Again in the case of same allocation in the allocation cell values, choose the minimum cost cell of transportation table formed in steps 1 to 3 .

Step 9:

Again if the cost cells and the allocations are equal, in such case choose the corresponding cell to the minimum of demand /supply which is to be allocated. Now if demand is satisfied delete the column and if it is supply delete the row.

Step 10:

Step 11:

Repeat step 6 and 7 until the demand and supply are satisfied.

Step 12:

Now transfer this allocation to the original transportation table.

Calculate the total transportation cost is equal to the sum of the product of cost and corresponding allocated value of the transportation table.

The total transportation cost obtained from proposed algorithm is minimum than the cost obtained from NWCM and VAM 
NUMERICAL EXAMPLE:

Consider the following Cost minimizing Transportation problem:

\begin{tabular}{|l|l|l|l|l|}
\hline & $\mathrm{D}_{1}$ & $\mathrm{D}_{2}$ & $\mathrm{D}_{3}$ & Supply \\
\hline $\mathrm{S}_{1}$ & 6 & 4 & 1 & 50 \\
\hline $\mathrm{S}_{2}$ & 3 & 8 & 7 & 40 \\
\hline $\mathrm{S}_{3}$ & 4 & 4 & 2 & 60 \\
\hline Demand & 20 & 95 & 35 & 150 \\
\hline
\end{tabular}

Applying the North West corner method, for initial basic feasible solution, the allocations are as follows.

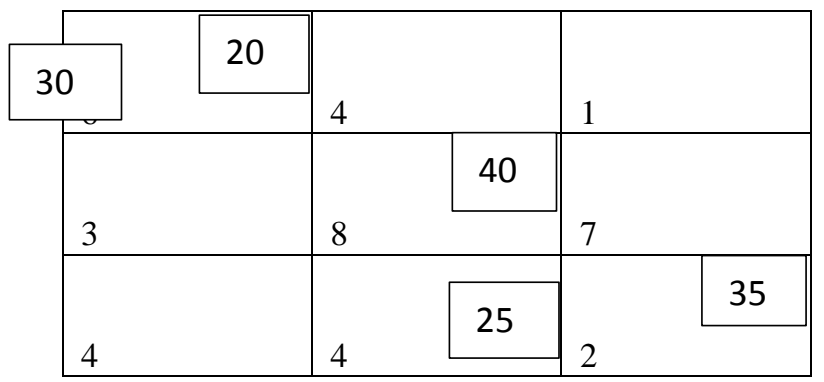

The Minimum cost using North West Corner Method is,

Minimum Cost $=(20 * 6)+(30 * 4)+(40 * 8)+(25 * 4)+(35 * 2)=730$

Applying the Vogel's Approximation Method for initial basic feasible solution, the allocations are as follows.

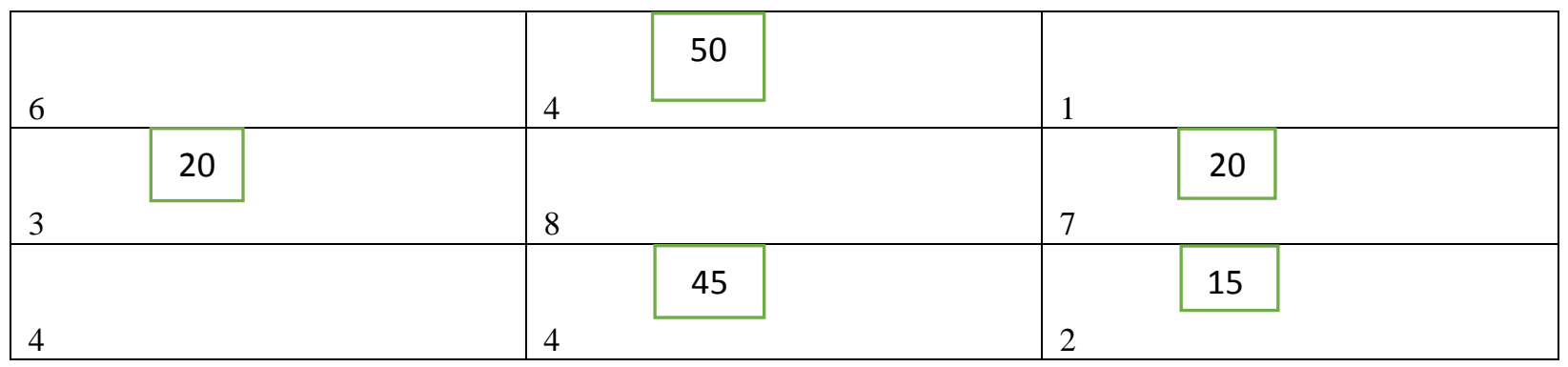

The Minimum cost using Vogel's Approximation Method is,

Minimum Cost $=(50 * 4)+(20 * 3)+(20 * 7)+(45 * 4)+(15 * 2)=610$

Now by applying the new method,

\begin{tabular}{|c|c|c|}
\hline $\begin{array}{l}5 \\
3\end{array} 6$ & $\begin{array}{l}34 \\
0\end{array}$ & $\begin{array}{ll}0 & 1 \\
0 & 1\end{array}$ \\
\hline $\begin{array}{ll}0 & 3 \\
0 & 3\end{array}$ & $\begin{array}{l}4 \\
5\end{array} 8$ & $\begin{array}{l}67 \\
4\end{array}$ \\
\hline$\frac{1}{2} 4$ & $\begin{array}{l}0 \\
2\end{array}$ & $\begin{array}{l}12 \\
0\end{array}$ \\
\hline
\end{tabular}

The allocation cell values are given in the following transportation table is, 


\begin{tabular}{|c|c|c|c|c|c|}
\hline 8 & & 3 & 15 & 0 & 35 \\
\hline & 20 & & 20 & \multirow{2}{*}{\multicolumn{2}{|c|}{10}} \\
\hline \multicolumn{2}{|c|}{0} & \multicolumn{2}{|c|}{9} & & \\
\hline & & & 60 & & \\
\hline
\end{tabular}

Total Cost obtained by new method is as follows,

Total Minimum cost $=(15 * 4)+(35 * 1)+(20 * 3)+(20 * 8)+(60 * 4)=555$

\section{CONCLUSION:}

The main aim of this paper is to achieve the optimal transportation cost by using the new method and it is very easy to understand. Based on the optimal solution it allows us to take a decision effectively. The decision maker goes through all the steps of algorithm which makes our approach very useful to solve real problems.

\section{REFERENCES:}

1. F.L. Hitchcock, "Distribution of a Product from several sources to numerals locations", Journal of Mathematical Physics, 20 (1941).

2. G.B. Dantzig, "Linear Programming and Extensions", Princeton University Press, Princeton, 1963.

3. G.Hadly, Linear Programming, Addison-Wesley, Publishing Company, 1974.

4. H.A.Taha, Operations Research and Introduction, fifth edition, Macmillan Publishing Company, USA, 1992.

5. Hamdy, A.T, Operations Research: An Introduction 8th Edition, Pearson Prentice Hall, Upper Saddle River, 2007

6. S.M.Abul Kalam Azad, Md. Bellel Hossain, Md. Mizanur Rahman, "An Algorithmic Approach To solve Transportation Problems with the Average Total Opportunity Cost Method", International Journal of Scientific and Research Publications, Volume 7,Issue 2, 2017

7. H.A.Taha, "Operation Research and Introduction", Sixth Edition, Prentice-Hall of India Private Limited, New Delhi.

8. Md.Mizanur Rahman, Dr.Md.Bellel Hossain and Dr.Md. Mosharraf Hossain," A New Approach for Minimization of Transportation Time: An Algorithmic Approach", Imperial Journal of Interdisciplinary Research, Vol-2, Issue-7, 2016

9. Mollah Mesbahuddin Ahmed, Aminur Rahman Khan, Md.Sharif Uddin, Faruque Ahmed," A New Approach to Solve Transportation Problems" open Journal of Optimization, 5, 22-30, 2016

10. Aminur Rahman Khan, Adorian Vilcu, Nahid Sultana and Syed Sabbir Ahmed", DETERMINATION OF INITIAL BASIC FEASIBLE SOLUTION OF A TRANSPORTATION PROBLEM: A TOCM-SUM APPROACH”, Buletinul Institutului Politechnic Din Iasi.t. (LXV), f.1, 2015

11. Z.A.M.S. Juman and N.G.S.A. Nawarathne, "An efficient alternative approach to solve a transportation problem" Ceylon Journal of Science 48(1): 19-29, 2019 